\title{
The Potential Impact of the Floating Exchange Rate Policy on the Egyptian Trade Balance, Agricultural Trade and Food Trade
}

\author{
Dr. Ahmed Qadry M. Bahloul *
}

Faculty of Technology and Development, University of Zagazig, Zagazig, Egypt. and, The University of Umm Al-Qura, the Holly Mecca, KSA.

\section{Abstract}

Egypt has a long history of problems regarding its exchange rate with US Dollar. Egypt decided to float its currency against the foreign currencies including the US Dollar on 3/11/2016. There is a great controversy among the economists concerning the policy impacts of the new policy. The research question was what is the expected impact of floating the Egyptian pound exchange rate on the trade balance, agricultural trade balance, and food trade balance? The research paper aims at studying the possible impact of exchange rate policy and the of total trade balance, agricultural trade balance, and food trade balance. Two econometric methods used for the estimation of export and import elasticities, the Feasible generalized least squares (FGLS) estimator and the Vector Error Autoregressive Models (VAR). The estimated Marshall-Lerner condition ranged from 1.72 to 1.92 for the Egyptian total trade, while ranged from 1.44 to 1.46 for the agricultural trade, while it is ranged from 0.64 to 2.09 in the case of food trade. The results indicated the validity of the MarshallLerner condition (MLC) for the Egyptian total trade, agricultural trade, and food trade. The new Egyptian floating exchange rate policy associated with institutional reforms will probably has positive impacts on the Egyptian trade, the agricultural trade, and the food trade.

JEL classifications: F4, Q17, Q18

Keywords: Egypt; Marshall-Lerner Condition; Trade, Agricultural Trade, Food Trade

\section{Introduction}

The exchange rate of Egyptian pound towards the foreign currencies especially the US Dollar is very controversial issue in Egypt. The underlying reason is its impacts on all the Egyptian economy sectors. There are many viewpoints of the Egyptian economists in addition to the IMF experts' advice. The exchange rate policy affects The Egyptian trade, agricultural trade, and food trade.

On 29 January 2003, the government of Egypt floated the Egyptian pound by allowing the Egyptian banks to determine the US $\$$ buy and sell prices within the free exchange rate market. The Central Bank of Egypt enforce the banks to sell $75 \%$ of foreign exchange and keeping the rest $(25 \%)$ in their accounts to fulfill their commitments. Because of this policy, the Egyptian pound devaluated on the end of June 2003 by $23.3 \%$. (The Central Bank of Egypt, 2003).

In the year 2003/2004, the exchange rate stability is retained, and the weighted average for US\$ reached 620.23 piasters by the end of June 2004. Which implies that

\footnotetext{
* Corresponding author Tel.: +201001982883, +966532058815; E-mail :drahmedbahloul@yahoo.com, aqbahloul@zu.edu.eg, ambahloul@uqu.edu.sa (Ahmed Qadry).
} 
the exchange rate of US\$ decreased by $2.7 \%$ during the year 2003/2004. (The Central Bank of Egypt, 2003).

The value of Egyptian pound against the US Dollar improved and become 5.80 pounds per US\$. The liberation of exchange rate increased the inflation rate to 15.9 $\%, 16.1 \%$, measured as WPI and CPI respectively. The international reserves increased from 14.8 billion US\$ by the end of June 2004 to 22.4 billion US\$ by the end of February 2006. (The Central Bank of Egypt, 2006).

The ex-prime minister of Egypt Dr. Kamal Al-Ganzouri states that Egypt cannot benefit from its pound devaluation because of the weakness of elasticity to exchange rate and undiversified exports. The depreciation of the Egyptian pound against US\$ will have the following consequences: 1) increasing the imports bill. 2) Increasing the foreign components in the Egyptian exports thus decrease its competitiveness. 3) Negative impact on balance of payments. 4) Increasing the budget deficit due to increasing the food subsidies burden. 5) Increasing inflation rate. 6) Escaping the foreign investors from financial market due to unstable exchange rate and dividends profits. 7) The foreign direct investment will suspend. 8) The majority of external transactions in US Dollars will stop. (Al-Ganzouri, K., 2013).

On Thursday 3/11/2016 Egyptian exchange policy transformed to the floating policy of the Egyptian pound against the foreign currencies including US \$. Since this date, a great debate started among the advocators and oppositions of this policy. Each team has economic and noneconomic justifications.

The free exchange rate and devaluation of the Egyptian pound were the traditional conditions of the IMF reform program for Egypt. Which aimed at eliminating the foreign exchange shortages. This suggested regime must be supported by the appropriate monetary policy to mitigate its negative consequences, especially surging inflation. (IMF, 2016).

The government announced in September 2017 that the Egyptian non-oil exports increased by $9.4 \%$. The increase of exports is due to the impact of the exchange rate liberation in November 2016 on the prices of low-level value chain exports such as vegetables, fruits, etc... The major part of impact deteriorated in importing production components by increasing its prices. They recommended solving the institutional problems that decrease the allocated investments to produce substitutes of the imported components. (The Egyptian Center of Economic Studies, 2017).

Table 1 summarizes the IMF classification of Egypt exchange rate regimes. According it, Egypt experienced various exchange rate regimes. At the end, Egyptian policymakers decided to follow the floating policy measures to resolve the foreign exchange shortages severe problem.

The aim of the free float of Egyptian pound on November 2016 is resolving foreign exchange crisis, however, its negative impacts like increasing inflation which decreasing the purchasing power of Egyptian households especially for the poor 
consequently, the government ability to mitigate the inflation effect will determine the impact of the free exchange rate float policy. (Multiplies Group, 2017).

In this paper, the research question summarizes as follows: what is the expected impact of the policy of floating the Egyptian pound exchange rate on the trade balance, agricultural trade balance, and food trade balance?. The research paper aims at studying the possible impacts of the exchange rate policy of the Egyptian pound on the of the total trade balance, the agricultural trade balance, and the food trade balance.

Table (1) The IMF classification of Egypt exchange rate regimes

\begin{tabular}{|c|l|}
\hline Year & \multicolumn{1}{c|}{ the IMF classification of Egypt exchange rate regimes } \\
\hline $\mathbf{2 0 1 7}$ & Flexible exchange rate \\
\hline $\mathbf{2 0 1 6}$ & $\begin{array}{l}\text { Floating } \\
\text { Other managed }\end{array}$ \\
\hline $\mathbf{2 0 1 5}$ & Stabilized arrangement \\
\hline $\mathbf{2 0 1 4}$ & Stabilized arrangement: Maintaining a de facto exchange rate anchor to US dollar. \\
\hline $\mathbf{2 0 1 3}$ & Crawl-Like arrangement \\
\hline $\mathbf{2 0 1 2}$ & Stabilized arrangement \\
\hline $\mathbf{2 0 1 1}$ & Crawl-like arrangement \\
\hline $\mathbf{2 0 1 0}$ & Other Managed Arrangement \\
\hline $\mathbf{2 0 0 9}$ & Other Managed Arrangement \\
\hline $\mathbf{2 0 0 7}$ & Managed floating with no predetermined path for the exchange rate \\
\hline $\mathbf{2 0 0 6}$ & Managed floating \\
\hline $\mathbf{2 0 0 5}$ & Other conventional fixed peg arrangements \\
\hline $\mathbf{2 0 0 4}$ & Managed floating \\
\hline $\mathbf{2 0 0 3}$ & Managed floating with no pre-determined path for the exchange rates \\
\hline $\mathbf{2 0 0 2}$ & Managed floating with no pre-determined path for the exchange rates \\
\hline $\mathbf{2 0 0 0 - 2 0 0 1}$ & "pre-announced horizontal band that is narrower than or equal to $+/-2 \% "$ \\
\hline $\mathbf{1 9 9 9}$ & "pre-announced horizontal band that is narrower than or equal to $+/-2 \% "$ \\
\hline $\mathbf{1 9 9 1 - 1 9 9 8}$ & Conventional Fixed Peg \\
\hline $\mathbf{1 9 7 0 - 1 9 9 0}$ & "pre-announced horizontal band that is narrower than or equal to $+/-2 \% "$ \\
\hline $\mathbf{S 0}$ & De facto peg \\
\hline
\end{tabular}

Source: (1970-2013) from (Massoud, A., and Willet, T., 2014), 2014 from (IMF, 2015), 2015 from (IMF, 2016), and 2016 from (IMF, 2017).

\section{Literature review}

The exchange rate is the number of units of certain currency (Egyptian pounds), which could be exchanged with a unit of other currency (US\$). The big changes in exchange rates might significantly affect exports and imports values. This is the underlying logic for supporting the policy of stable exchange rate to facilitate the international trade flows. The bilateral exchange rate between the two countries affected by factors such as interest rates, inflation rates, income growth rates, economic growth rates, and the psychological factors. Exchange rate policies aimed at stabilizing the exchange rates by many measures such as: 1) Keep fixed exchange rates between the two countries. 2) Establishing monetary union by merging the currencies among countries in addition to coordinating the policies of interest rates, taxes, and government expenditures such as European Community. 3) Temporary market Intervention by selling or buying currencies within a certain band. (Skoburg, J., 2001). 
Professor Edward Schuh was the pioneer of the researches on the important role of the exchange rate in agriculture. The economic literature contains many arguments, theoretical Proves, and applied analysis regarding the role of exchange rate in agriculture, especially agricultural trade. According to the economic theory, the exchange rate plays an important role in the determination of agricultural prices, consequently affects the agricultural trade. The main issue in the economic theory is its impact on agricultural prices and trade. (Kristink, J. and Anderson, D., 2002).

Egypt devaluated its currency and liberalized the exchange rate and the trade policy by removing most of the quantitative restrictions, decreasing tariffs rates in addition to the unification of tariffs types of some products. The negative impact of these reforms was increasing the inflation pressures. Otherwise, the industry and agriculture sectors responded somewhat to the trade and exchange rate policy reforms by increasing the trade to GDP ratio slightly in comparison to some developing countries. Meanwhile, there was a room for the reform of trade and exchange rate policies because these policies were against exports. The overvaluation of the exchange rate favoring the resources allocation in the import substitutes industries. (Assistant for Trade Policy Reform Project, 2004).

The third Egyptian trade policy review for the year 2005 by WTO concludes that Egypt was managed a system of floating the Egyptian pound without predetermined path. The Central Bank was responsible about the monetary and exchange rate policy, and controlling the banking system. Since January 2, 2005, Egypt accepted the article VIII and paragraphs (2:4) of the IMF treaty. Egypt devaluated the Egyptian pound after strictly fixing it against the US\$ for a decade. On January 2003, the government applied a floating system without the predetermined path of the exchange rate, followed by additional devaluation to improve the trade balance by increasing export commodities and decreasing the commodities imports. On March 2003, the government enforced the exporters to sell $75 \%$ of foreign currencies to the governmental banks, but this measure suspended in the year 2004. Subsequently, the informal market for exchange rate disappeared actually. (WTO, 2005).

A literature review study aimed at scanning the economic literature regarding the Marshall-Learner condition (MLC) empirical tests concludes that the depreciation of exchange rate is usually thought to support the country trade balance, but the empirical results do not fulfill this assumption. In addition, $50 \%$ of the cases where the M-L condition appeared valid were statistically insignificant. Whereas the cases of statistically significant represent $30 \%$ of the total reviewed studies. For this reason, the conclusion of the benefit of currency devaluation should be considered carefully. The study also performed analysis for 29 countries, concluded the models have misspecification, and failed to estimate significant import and export elasticities, and the lack of scientific evidence of the M-L condition seems unlikely to be resolved in the near future. (Bahmani, M., Harvey, H., and Hegerty, S., 2013).

A study aims at forecasting the impact of the Egyptian exchange rate on exports concludes that the promotion of Egyptian exports is not depended entirely on the 
exchange rate, but affected by behavioral and institutional problems. For this reason, policy reforms and institutional framework are crucial for solving the weakness of export performance and improve the Egyptian economy responsiveness to economic prices like exchange rate. The policy implication of this conclusion is the policy and institutional reforms are prerequisites to benefit from exports from Egyptian pound devaluation. (Al-Showery, S., 1999).

\section{Model and data}

The research depends on the international economic theory, especially the Marshall-Lerner Condition to study the impact of Egyptian pound depreciation on the improvement of trade balances, and thus the balance of payments. The MarshallLerner Condition includes that the depreciation of real exchange rate will improve the current account, if the quantities of both exports and imports have the relatively elastic response to the real exchange rate, with the assumption of constant disposable income, which implies improving the Current account. The condition states that the sum of the elasticity of export demand and the elasticity of import demand to the real exchange rate is greater than one. i.e. $\boldsymbol{\eta}+\boldsymbol{\eta}>\mathbf{1}$. This condition implies that if the current account equal to zero, the devaluation of the currency will cause the surplus. Meanwhile, if its value is not equal zero, the condition will be more complex. Sometimes the current account will become worse immediately after devaluation and improved later on after some months. The J-curve depicts the time lag response required for the improvement of the current account. (Krugman and Obstfeld, 2003).For the majority of countries, the elasticities of exports are very small, thus the sum of both exports and imports elasticities is less than one. Which means fail to meet the M-L condition and supporting the existence of the J-curve effect (Krugman, P., Obstfeld, M., and Melitz, M., 2012).

The required condition for real devaluation to improve the balance of the current account is as follows:

$$
\left|\mathbf{e}_{\mathbf{x}}\right|+\left|\mathbf{e}_{\mathbf{m}}\right|>\mathbf{1}
$$

Where $\mathbf{e}_{\mathbf{x}}$ is a country's elasticity of foreign demand for exports, while $\mathbf{e}_{\mathbf{m}}$ represents the country's elasticity of import demand. The validity of this condition relies on the response of exports and imports to the real exchange rate. (Koo, W., and Kennedy. 2005).

The assumptions of the Marshall-Lerner condition (MLC) encompass the perfect competition, one export commodity, and one import commodity, in addition to full employment. The debates among economists on exchange rate devaluation effectiveness due to suspicions concerning the estimation methodologies of elasticity coefficient for exports and imports. The methodological problems include identification problem and the need for simultaneous equations estimation, aggregation due to using indexes, and time lags of using unit values, and the size effect of the change in elasticity amount. The majority of the foreign exchange earnings of tourism, remittances, and other services are more sensitive to the exchange rate. The World Bank concluded that Egypt exchange rate took 1-1.5 years 
for non-oil manufactured exports to rise significantly during the current study period. (Ikram, K., 2006).

The steps of the study applied are as follows: 1)Estimating export and import response equation to the real exchange rate of Egypt using the Ordinary Least Squares Method (OLS), The Generalized Least Square Method (FGLS), The Vector Error Autoregressive Models (VAR). 2) Estimating the export and import elasticities from steps (1). 3) Applying the Marshall-Lerner Condition (MLC).

The Generalized Least Square Method (FGLS) is a method with two-step .In step 1 we obtain an estimate of the unknown $\rho$ and in step 2, and use that estimate to transform the variables to estimate the generalized difference equation, which is GLS. EGLS with Prais-Winsten transformation and the Cochrane-Orcutt iterative procedure are techniques used in FGLS. (Gujarati, D. and Porter, D., 2009).

According to the LIMDEP Version 10 Econometric Modeling Guide, the default estimator in NLOGIT5TM software is the iterative Prais-Winsten algorithm. That is, the first observation is not discarded; the full GLS transformation is used. This is a repeated two-step estimator:

Step 1. OLS regression of $y$ on $X$. Then, estimate $\rho$ with $r=1-1 / 2 \times$ DurbinWatson statistic. Step 2. OLS regression of the following equation(2):

$$
\begin{aligned}
& y_{1}^{*}=\left(1-r^{2}\right)^{1 / 2} y_{1} \\
& y_{t}^{*}=y_{t}-r y_{t-1}, t=2, \ldots, T
\end{aligned}
$$

on the same transformation of $\mathrm{x}_{\mathrm{t}}$.

After Step 2, $r$ is recomputed based on the GLS estimator, and the regression is repeated. This iteration continues until the change in $r$ from one iteration to the next is less than 0.0001. The iterative Cochrane-Orcutt estimator and the maximum likelihood estimator are the other procedures to estimate linear regression with correcting the first order autocorrelation (Greene, W., 2012).

The Vector Error Autoregressive Models (VAR) is a general framework to describe the dynamic interrelationship between stationary variables. Thus, if $\mathrm{y}$ and $\mathrm{x}$ are stationary $\mathrm{I}(0)$ variables, the following system is used (3).

$$
\begin{aligned}
& y_{t}=\beta_{10}+\beta_{11} y_{t-1}+\beta_{12} x_{t-1}+v_{t}^{y} \\
& x_{t}=\beta_{20}+\beta_{21} y_{t-1}+\beta_{22} x_{t-1}+v_{t}^{x}
\end{aligned}
$$

On the other hand, if $y$ and $x$ are I(1) variables but are not cointegrated, we examine the interrelation between them using a VAR framework in first differences in the following system(4):

$$
\begin{aligned}
& \Delta y_{t}=\beta_{11} \Delta y_{t-1}+\beta_{12} \Delta x_{t-1}+v_{t}^{\Delta y} \\
& \Delta x_{t}=\beta_{21} \Delta y_{t-1}+\beta_{22} \Delta x_{t-1}+v_{t}^{\Delta x}
\end{aligned}
$$


Where $\Delta y_{t}=$ the first difference in Y variable and $\Delta x_{t}=$ the first difference in X. (Hill, R., Griffiths, W., and Lim, G., 2011).

The data and the variables names are presented in Table 1 in the appendix. Figs. 1-2 illustrated the study variables behavior. The stationary property of the time series data is an important to estimate the best time series econometric models. According to the Figs. 1-2 the variables looks non-stationary time series. Lack of stationary property will guide the econometric methods of estimating exports and imports regression equations.

Fig.1. Stationary and Nonstationary Variables Graphs 1990-2016
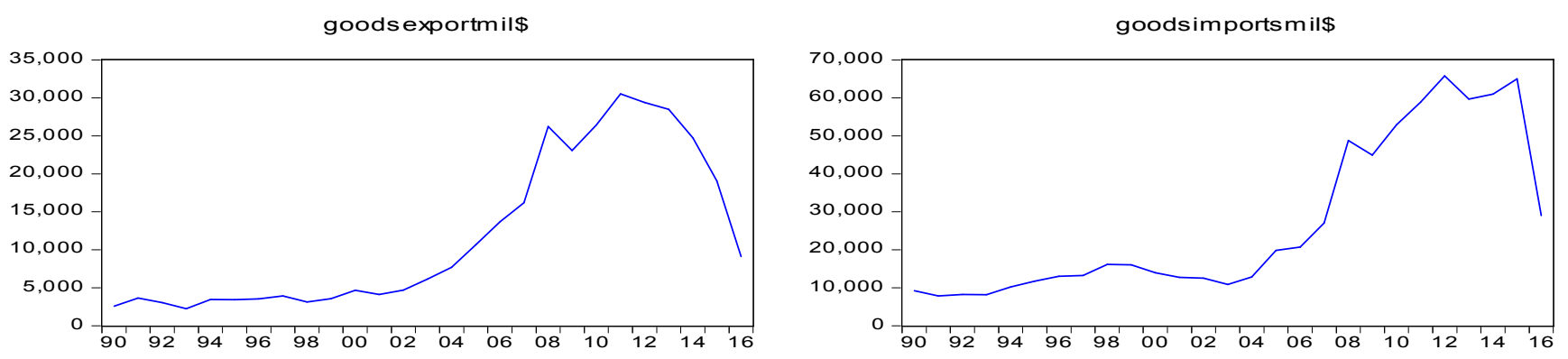

RERmodern
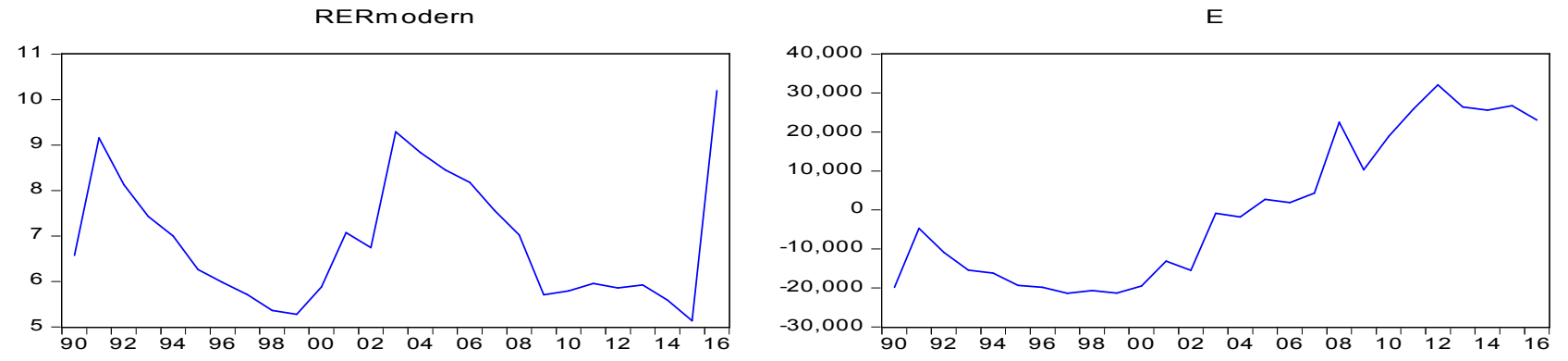

Fig.2. Stationary and Nonstationary Variables Graphs 1990-2013
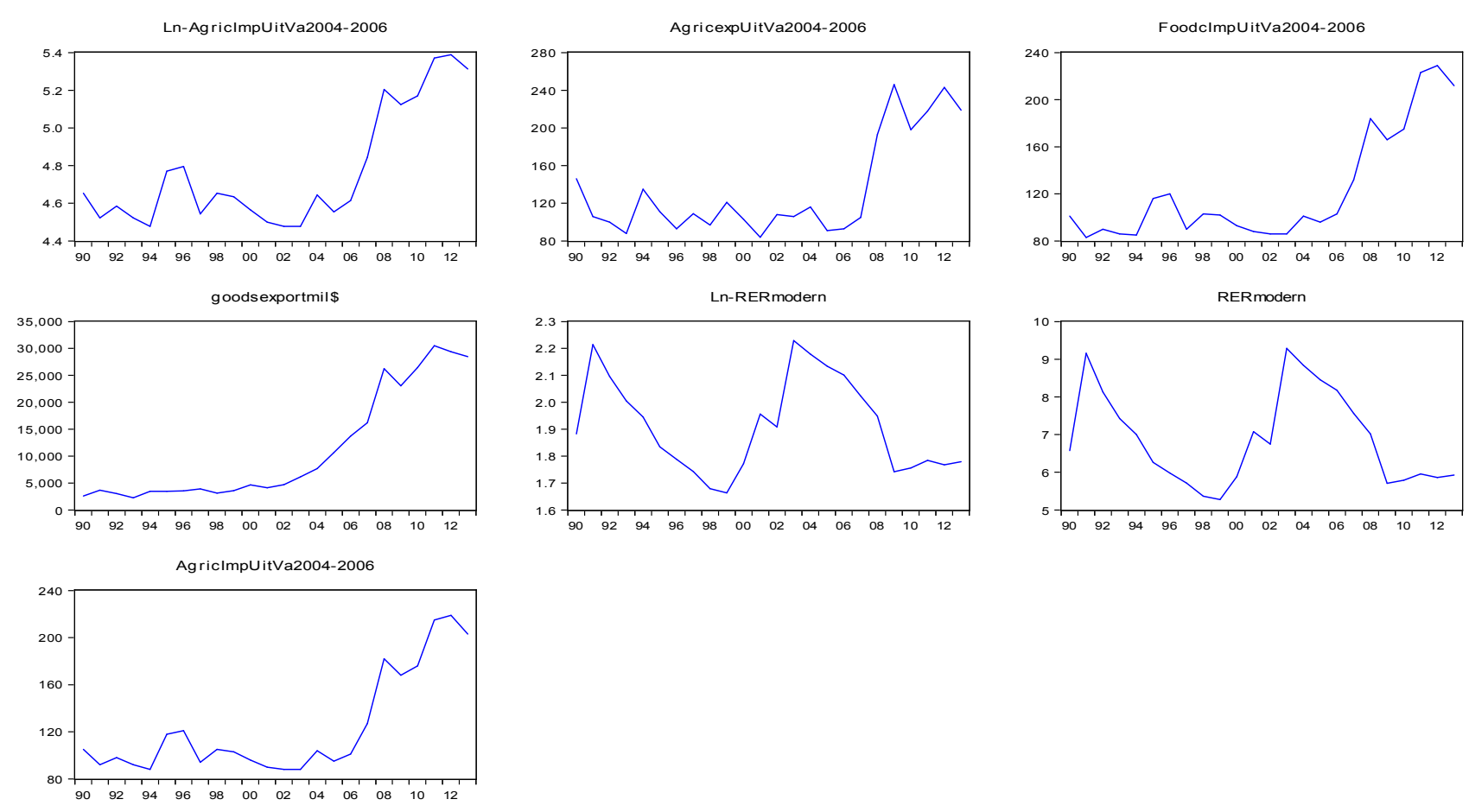


\section{Estimation results and the implications}

The estimations of export and import elasticities and Marshall-Learner condition for the Egyptian trade, agricultural trade, and food trade during the period (1990-2016) by OLS, Cochrane-Orcutt, and Parais-Winsten methods, In addition to the VAR models.

The estimation of the models started with the models with autocorrelation by estimating OLS firstly and then estimate the model with the Feasible generalized least squares (FGLS) estimator with Prais-Winsten, Chochrane-Orcutt, and Maximum Likelihood techniques using the NLOGIT5TM software. (Greene, W., 2012). While the estimation of regression with time-series data by using nonstationary variables and Vector Error Autoregressive Models (VAR) were by using EViewsTM software, and Gretl software. (Griffiths, W., Hill, R., and Lim, G., 2012).

Results and diagnostics are presented for both transformed and untransformed models. The example below shows the specific results given.

The Fig. 3 depicts the methodology applied in the study that depends on the mainstream time series econometric analysis in the literature. (Bahloul, A.Q., 2012).

Fig.3 The Applied Time Series Econometric Methodology



Source: Adapted from: (Bahloul, A.Q., 2012)

Estimation results are presented in Tables 1-2, respectively for both OLS and FGLS econometric estimation methods and VAR models. For the trade, agricultural trade, and food trade, the results confirmed the validity of Marshall-Lerner condition. 
Table (2) showed the estimates of the export and import Elasticities and verification of the Marshall- Learner condition for the Egyptian trade, the agricultural trade and the food trade during the period (1990-2016). The elasticity of goods exports and imports are -0.57 and -1.15 respectively and the Marshal-Lerner Condition (MLC) is 1.72 . While, the elasticity of agricultural exports and imports are -0.750 .69 respectively, and the Marshal-Lerner Condition (MLC) is 1.44 . For the food trade, the elasticity of food exports and imports are -0.35 and -0.28 respectively and the Marshal-Lerner Condition (MLC) is 0.64. According these results the Marshal-Lerner Condition (MLC) is apparently valid for both the total trade and the agricultural trade, while it is not valid for the food trade.

Table (3) displayed the estimates of the export and import Elasticities and the Marshall Learner conditions from VAR Models for the Egyptian trade, agricultural trade and food trade during the period (1990-2016). The elasticity of goods exports and imports are 0.77 and -1.15 respectively and the Marshal-Lerner Condition (MLC) is 1.92. While, the elasticity of agricultural exports and imports are $-0.69-0.77$ respectively, and the Marshal-Lerner Condition (MLC) is 1.46. For the food trade, the elasticity of food exports and imports are 1.31 and 0.78 respectively and the Marshal-Lerner Condition (MLC) is 2.09. According these results the Marshal-Lerner Condition (MLC) is valid for the total trade, the agricultural trade and the food trade. Since these results are generally confirmed the table 1 results, thus the important implication of these results is the validity of the Marshall-Lerner conditions support the floating policy for exchange rate. The devaluation of the Egyptian currency against US dollar will probably improve the Egyptian total trade, agricultural trade, and food trade. 
Table (2): Estimates of The Export and Import Elasticities and Marsh all Learner condition for the Egyptian trade, the agricultural trade and the food trade during the period (1990-2016)

\begin{tabular}{|c|c|c|c|c|c|c|c|c|c|c|c|}
\hline period & $\begin{array}{l}\text { Dependent } \\
\text { variables }\end{array}$ & Mean & $\begin{array}{c}\text { Independent } \\
\text { Variables }\end{array}$ & Mean & $\begin{array}{l}\text { Method of } \\
\text { Estimation }\end{array}$ & $\begin{array}{l}\text { Function } \\
\text { form }\end{array}$ & B & $\mathbf{T}$ & $\mathbf{p}$ & Elasticity & MLC \\
\hline $1990-2016$ & goodsexpor $\sim 1$ & 11761.36 & RERmodern & 6.89 & OLS-Cochrane-Orcutt & Linear & -981.33 & -1.96 & 0.05 & -0.57 & \\
\hline 1990-2016 & goodsimpor $\sim$ I & 27052.36 & RERmodern & 6.89 & OLS-Prais-Winsten & Linear & -4503.89 & -4.44 & $\mathbf{0 . 0 0}$ & -1.15 & 1.72 \\
\hline $1990-2013$ & Ln-AgricImpUi 6 & 4.84 & LN-RERmodern & 1.91 & OLS-Prais-Winsten & Exponential(Double-Log) & -0.75 & -2.11 & 0.04 & -0.75 & \\
\hline $1990-2013$ & AgricexpUi 6 & 134.54 & RERmodern & 6.88 & OLS-Prais-Winsten & Linear & -13.47 & -2.00 & 0.05 & -0.69 & 1.44 \\
\hline $1990-2013$ & FoodcImpUi $\sim 6$ & 122.92 & RERmodern & 6.88 & OLS-Cochrane-Orcutt & Linear & -5.07 & -1.13 & 0.26 & -0.28 & \\
\hline $1990-2013$ & FoodcexpUi $\sim 6$ & 148.79 & RERmodern & 6.88 & OLS-Cochrane-Orcutt & Linear & -7.66 & -0.88 & 0.38 & -0.35 & 0.64 \\
\hline
\end{tabular}

OLS: Ordinary Least Squares

Source: Estimated from Table (1) in the Appendix.

Table(3): Estimates of The Export and The Import Elasticities and The Marshall Learner condition from VAR Models for The Egyptian Trade Agricultural Trade and The Food Trade during the period (1990-2016)

\begin{tabular}{|c|c|c|c|c|c|c|c|c|c|c|}
\hline period & Dependent variables & Mean & $\begin{array}{c}\text { Independent } \\
\text { Variables } \\
\end{array}$ & Mean & Function form & B & $\mathbf{T}$ & $\mathbf{p}$ & Elasticity & MLC \\
\hline $1990-2016$ & goodsexpormil & 12114.29 & RERmodern_1 & 6.76 & Linear & 1365.06 & 2.173 & 0.041 & 0.77 & \\
\hline $1990-2016$ & goodsimportsmil & 27738.39 & RERmodern & 6.89 & Linear & -4642.16 & -4.167 & 0.000 & -1.15 & 1.92 \\
\hline 1990-2013 & Ln-AgricImpUitva 2004-2006 & 4.81 & LN-RERmodern_2 & 1.93 & Exponential (Double-Log) & -0.77 & -1.83 & 0.091 & -0.77 & \\
\hline $1990-2013$ & AgricexpUitva 2004-206 & 134.04 & RERmodern & 6.88 & Linear & -13.47 & -1.83 & 0.084 & -0.69 & 1.46 \\
\hline $1990-2013$ & FoodcImpUitva 2004-2006 & 129.50 & RERmodern_4 & 7.08 & Linear & 14.35 & 2.53 & 0.025 & 0.78 & \\
\hline $1990-2013$ & FoodcexpUiva 2004-2006 & 158.00 & RERmodern_5 & 7.15 & Linear & 28.88 & 2.00 & 0.071 & 1.31 & 2.09 \\
\hline
\end{tabular}

Source: Estimated from Table (1) in the Appendix. 


\section{Conclusion}

The literature survey has indicated that the Marshall-Lerner condition (MLC) is not valid for Egypt. This study has the opposite conclusion. By applying two mainstream econometric methods, the results indicated the apparent validity of the Marshall-Lerner condition (MLC) for the Egyptian total trade, agricultural trade, and probably food trade. The new Egyptian floating exchange rate policy associated with institutional reforms will probably has positive impacts on the Egyptian trade, the agricultural trade, and the food trade. The magnitude of the impact will vary among the different types of the exports and the imports in addition to the accompanying policy and institutional reforms.

\section{References}

- Al-Ganzouri, K., 2013. Al-Ganzouri Silence while the Media did not Silence,AlShorouq, Cairo, First ed. 240-241.

- Al-Showery, S., 1999. Forecasting the Impact of the Egyptian Exchange Rate on Exports, USAID, Cairo, October 1999.

- Assistant for Trade Policy Reform Project.2004.Impact of Trade and Economic Policy Reforms on Key Sectors of Egyptian Economy, Final Report, Submitted by Nathan Associates to USAID/Cairo, VI-V11.

- Bahloul, A.Q., 2012. The Egyptian Trade Policy Strategy of Development and The Global Trading System in The WTO Era, Egyptian Association of Agricultural Economics, Egyptian Journal of Agricultural Economics, 22, 1, March 2012, 308.

- Bahmani, M., Harvey, H., and Hagerty, S., 2013. Empirical tests of The MarshallLerner Condition: a Literature Review, Journal of Economic Studies, 40, 3, 411\& 436-439.

- Diakosavvas, D., and Kirkpatrick, C., 1990. The Effects of Trade and Exchange Rate Policies on Production Incentives in Agriculture, FAO Economic and Social Development Paper 96, FAO, Rome,16-17.

- Food and Agriculture Organization of the United Nations (FAO), FAOSTAT, [online].Available at http://www.fao.org/faostat/en/\#data, Accessed July 22, 2017.

- Greene, W., 2012. Econometric Analysis, Perarson Education Inc., Prentice Hall, Boston, USA, 927-928.

-Greene, W., 2012. LIMDEP version 10 Econometric Modeling Guide, Econometric Software Inc., USA, E232-E234.

- Gujarati, D., and Porter, D., 2009.Basic Econometrics, the $5^{\text {th }}$ ed., McGraw-Hill International Edition, New York, 447.

- Hill, R., Griffiths, W., and Lim, G., 2011. Principles of Econometrics, 4th ed., John Willey \& Sons, Inc., New York, 499.

- Hill, R., Griffiths, W., and Lim, G., 2012. Using Eviews: For Principles of Econometrics, John Wiley Sons, Inc. New York, 325-337.

- Ikram, K., 2006. The Egyptian Economy, 1952-2000: Performance, Policies, and Issues, Routledge, London. 
- International Monetary Fund (IMF), 2015.Annual Report on Exchange Arrangements and Exchange Restrictions, October.

- International Monetary Fund (IMF), 2016.Annual Report on Exchange Arrangements and Exchange Restrictions, October 2016, 4. 9.

- International Monetary Fund (IMF), 2016.IMF Executive Board Approves US\$12 billion Expected Arrangement under the Extended Fund Facility for Egypt, Press Release No.16/501, November11,2016,2.

- International Monetary Fund (IMF), 2017.IMF Executive Board Completes First Review under the Extended Fund Facility (EFF) with the Arab Republic of Egypt, July 2017, 4.

- International Monetary Fund (IMF), 2017.International Financial Statistics, August 2017, World \& Country Notes, IMF, 119.

International Monetary Fund (IMF), IFS, [online].Available athttp://data.imf.org/regular.aspx?key=61545854, Accessed on July 22, 2017.

- Koo, W., and Kennedy, P. 2005.International Trade and Agriculture, Blackwell Publishing, Malden, MA, USA, 204-205.

- Kristinek, J. and Anderson, D., 2002.Exchange Rates and Agriculture: A Literature Review, Agricultural and Food Policy Center, Department of Agricultural Economics, Texas A\&M University, 31.

- Krugman, P., and Obstfeld, M., 2003. International Economics: Theory and Policy, Sixth ed.; Boston: Pearson Education, 477-479\& 463-464.

- Krugman, P., Obstfeld, M., and Melitz, M., 2012. International economics: Theory \&Policy, $9^{\text {th }}$ ed. Addison-Wesley, Pearson, Boston, USA, 462.

- Massoud, A., and Willet, T., 2014. Egypt's Exchange Rate Regime Policy after the Float, International Journal of Social Sciences Studies, Redfame Publishing,[ONLINE].Available at ' http://ijss.redfame.com' 2,4,October 2014,12.

- Multiplies Group, 2017. Egypt's Free Floating Exchange Regime: Causes and Consequences, Issues\#9, January 2017, 12.

- Skorburg, J.2001. Exchange Rates and Agricultural Trade: Is the Dollar Too High? In American Farm Bureau Federation, The Voice of Agricultural Issues, [online].Available at 'URL:http://www.fb.org/issues/analysis/Is Dollar too High.html' Accessed on June 27, 2006, 1-2.

- The Central Bank of Egypt, 2003. The Annual Report for the Year 2002/2003, Cairo: The Central Bank of Egypt, 24, 20-21.

- The Egyptian Center of Economic Studies, 2017. View in News, [online].Available at http://www.ecesnews@eces.org.eg Accessed September 20, 2017, 2.

- WTO.2005. Trade Policy Review on Egypt, Report on Egypt: Report by the Secretariat, No. WT/TPR/S/150, 28 June 2005. 2-3.

- Zaki, C., Ehab, M., and Abdallah, A. 2017. How Do Trade Margins Respond to the Exchange Rate? The case of Egypt, The Egyptian Center for Economic Studies (ECES), Cairo, 2. 
Appendix

Table (1) The Model Variables and Data during period 1990-2016

\begin{tabular}{|c|c|c|c|c|c|c|c|c|c|c|c|c|c|c|}
\hline Variable & $\begin{array}{c}\text { goodsexp } \\
\text { ortmil\$ }\end{array}$ & $\begin{array}{c}\text { goodsimpo } \\
\text { rtsmil\$ }\end{array}$ & LEper\$end & $\begin{array}{c}\text { ProdPriceI } \\
\text { ndexUSA2 } \\
010\end{array}$ & $\begin{array}{l}\text { CPIWorld } \\
2010\end{array}$ & $\begin{array}{l}\text { CPIUSA } \\
2010\end{array}$ & $\begin{array}{c}\text { CPIEgyp } \\
\text { t } 2010\end{array}$ & $\begin{array}{l}\text { USAWPI } \\
2010\end{array}$ & $\begin{array}{l}\text { WorldWPI } \\
2010\end{array}$ & $\begin{array}{c}\text { AgricImpU } \\
\text { itVa2004- } \\
2006 \\
\end{array}$ & $\begin{array}{l}\text { AgricexpUitVa } \\
\mathbf{2 0 0 4 - 2 0 0 6}\end{array}$ & $\begin{array}{l}\text { FoodcImpUitVa } \\
\text { 2004-2006 }\end{array}$ & $\begin{array}{c}\text { FoodcexpU } \\
\text { itVa2004- } \\
2006 \\
\end{array}$ & $\begin{array}{c}\text { RERmo } \\
\text { dern }\end{array}$ \\
\hline Year & $\begin{array}{c}\text { Goods } \\
\text { Exports } \\
\text { Millions } \\
\text { US\$ }\end{array}$ & $\begin{array}{l}\text { Goods } \\
\text { Imports } \\
\text { Millions } \\
\text { US\$ }\end{array}$ & $\begin{array}{l}\text { Exchange } \\
\text { rate LE/ } \\
\text { US\$ }\end{array}$ & $\begin{array}{l}\text { Producer } \\
\text { Price } \\
\text { Index for } \\
\text { USA } \\
\text { 2010=100 }\end{array}$ & $\begin{array}{l}\text { CPI World } \\
2010=100\end{array}$ & $\begin{array}{c}\text { CPI USA } \\
2010=10 \\
0\end{array}$ & $\begin{array}{c}\text { CPI } \\
\text { Egypt } \\
2010=100\end{array}$ & $\begin{array}{c}\text { WPI } \\
\text { USA } \\
2010=10 \\
0\end{array}$ & $\begin{array}{c}\text { WPI } \\
\text { World } \\
2010=100\end{array}$ & $\begin{array}{c}\text { Agricultur } \\
\text { al Imports } \\
\text { Unit Value } \\
\text { Index } \\
2004 / 2006= \\
100\end{array}$ & $\begin{array}{c}\text { Agricultural } \\
\text { Exports Unit } \\
\text { Value Index } \\
\mathbf{2 0 0 4 / 2 0 0 6 = 1 0 0}\end{array}$ & $\begin{array}{l}\text { Food Imports } \\
\text { Unit Value Index } \\
2004 / 2006=100\end{array}$ & $\begin{array}{c}\text { Food } \\
\text { Exports } \\
\text { Unit Value } \\
\text { Index } \\
\text { 2004/2006= } \\
100\end{array}$ & $\begin{array}{c}\text { Real } \\
\text { Exchang } \\
\text { e Rate } \\
\text { by } \\
\text { Modern } \\
\text { Approac } \\
\text { h }\end{array}$ \\
\hline 1990 & 2585.15 & 9215.50 & 2.00 & 62.92 & 21.54 & $\mathbf{5 9 . 9 2}$ & 19.15 & 62.92 & 27.93 & 105.00 & 146 & 101 & 105 & 6.57 \\
\hline 1991 & 3659.00 & 7861.80 & 3.33 & 63.06 & 25.32 & 62.46 & 22.93 & 63.06 & 31.85 & 92.00 & 106 & 83 & 121 & 9.16 \\
\hline 1992 & 3051.30 & 8244.70 & 3.34 & 63.44 & 29.66 & 64.35 & 26.06 & 63.44 & 36.45 & 98.00 & 100 & 90 & 118 & 8.13 \\
\hline 1993 & 2243.90 & 8184.20 & 3.37 & 64.37 & 35.29 & 66.25 & 29.21 & 64.37 & 42.73 & 92.00 & 88 & 86 & 113 & 7.43 \\
\hline 1994 & 3463.30 & 10185.10 & 3.39 & 65.20 & 44.87 & 67.98 & 31.59 & 65.20 & 54.00 & 88.00 & 135 & 85 & 112 & 7.00 \\
\hline 1995 & 3434.70 & 11738.80 & 3.39 & 67.53 & 51.63 & $\begin{array}{ll}69.88 \\
\end{array}$ & 36.56 & $\begin{array}{l}67.53 \\
\end{array}$ & 62.32 & 118.00 & 111 & 116 & 108 & 6.26 \\
\hline 1996 & 3534.50 & 13018.60 & 3.39 & 69.12 & 56.00 & 71.93 & 39.19 & 69.12 & 66.30 & 121.00 & 93 & 120 & 101 & 5.98 \\
\hline 1997 & 3920.60 & 13211.13 & 3.39 & 69.07 & 59.38 & 73.61 & 41.00 & 69.07 & 69.40 & 94.00 & 109 & 90 & 109 & 5.71 \\
\hline 1998 & 3130.43 & 16166.17 & 3.39 & 67.36 & 62.66 & 74.76 & 42.59 & 67.36 & 71.59 & 105.00 & 97 & 103 & 96 & 5.36 \\
\hline 1999 & 3559.36 & 16022.11 & 3.41 & 67.92 & 66.16 & 76.39 & 43.90 & 67.92 & 74.67 & 103.00 & 121 & 102 & 96 & 5.28 \\
\hline 2000 & 4674.90 & 13963.00 & 3.69 & 71.85 & 69.20 & 78.97 & 45.08 & 71.85 & 80.36 & 96.00 & 103 & 93 & 93 & 5.88 \\
\hline 2001 & 4127.30 & 12750.10 & 4.49 & 72.64 & 72.16 & 81.20 & 46.10 & 72.64 & 83.10 & 90.00 & 84 & 88 & 74 & 7.07 \\
\hline 2002 & 4686.70 & 12496.10 & 4.50 & 70.98 & 74.53 & 82.49 & 47.36 & 70.98 & 84.84 & 88.00 & 108 & 86 & 78 & 6.74 \\
\hline 2003 & 6162.80 & 10878.10 & 6.15 & 74.77 & 77.13 & 84.36 & 49.50 & 74.77 & 89.11 & 88.00 & 106 & 86 & 83 & 9.29 \\
\hline 2004 & 7682.80 & 12831.40 & 6.13 & 79.39 & 79.93 & 86.62 & 55.08 & 79.39 & 94.46 & 104.00 & 116 & 101 & 94 & 8.84 \\
\hline 2005 & 10652.20 & 19815.60 & 5.73 & 85.20 & 82.97 & 89.56 & 57.76 & 85.20 & 100.00 & 95.00 & 91 & 96 & 101 & 8.45 \\
\hline 2006 & 13694.40 & 20722.40 & 5.70 & 89.18 & 85.96 & 92.45 & 62.17 & 89.18 & 105.09 & 101.00 & 93 & 103 & 105 & 8.18 \\
\hline 2007 & 16200.40 & 27063.30 & 5.50 & 93.46 & 89.17 & 95.09 & 67.97 & 93.46 & 110.04 & 127.00 & 105 & 132 & 127 & 7.56 \\
\hline 2008 & 26246.30 & 48774.60 & 5.50 & 102.63 & 94.32 & 98.74 & 80.42 & 102.63 & 120.31 & 182.00 & 193 & 184 & 235 & 7.02 \\
\hline 2009 & 23061.90 & 44946.10 & 5.48 & 93.60 & 96.58 & 98.39 & $\begin{array}{l}89.88 \\
\end{array}$ & 93.60 & 115.49 & 168.00 & 246 & 166 & 317 & 5.71 \\
\hline 2010 & 26437.80 & 52922.80 & 5.79 & 100.00 & 100.00 & 100.00 & 100.00 & 100.00 & 100.00 & 176.00 & 198 & 175 & 246 & 5.79 \\
\hline 2011 & 30527.60 & 58903.10 & 6.02 & 108.83 & 104.79 & 103.16 & 110.05 & 108.83 & & 215.00 & 218 & 223 & 289 & 5.95 \\
\hline 2012 & 29409.20 & 65774.40 & 6.31 & 109.43 & 108.79 & 105.29 & 117.89 & 109.43 & & 219.00 & 243 & 229 & 353 & 5.86 \\
\hline 2013 & 28493.00 & 59661.70 & 6.94 & 110.11 & 112.75 & 106.83 & 128.99 & 110.11 & & 203.00 & 219 & 212 & 297 & 5.92 \\
\hline 2014 & 24735.75 & 61010.44 & 7.14 & 111.14 & 116.41 & 108.57 & 142.08 & 111.14 & & & & & & 5.59 \\
\hline 2015 & 19051.26 & 65043.93 & 7.81 & 103.09 & 119.64 & 108.70 & 156.80 & 103.09 & & & & & & 5.13 \\
\hline 2016 & 9130.20 & 29008.50 & 18.13 & 100.35 & 122.84 & 1110.07 & 178.46 & 100.37 & & & & & & 10.19 \\
\hline Source & $\begin{array}{c}\text { IMF,IFS, } \\
\text { CBE } \\
\text { External } \\
\text { Position }\end{array}$ & IMF,IFS & IMF,IFS & IMF,IFS & IMF,IFS & IMF,IFS & IMF,IFS & IMF,IFS & $\begin{array}{c}\text { World } \\
\text { Bank, } \\
\text { World } \\
\text { Developme } \\
\text { nt } \\
\text { Indicators }\end{array}$ & $\begin{array}{l}\text { FAO,FAO } \\
\text { STAT }\end{array}$ & $\underset{T}{\text { FAO,FAOSTA }}$ & FAO,FAOSTAT & $\begin{array}{l}\text { FAO,FAO } \\
\text { STAT }\end{array}$ & \\
\hline
\end{tabular}

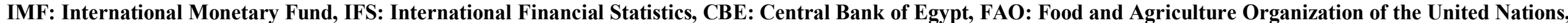

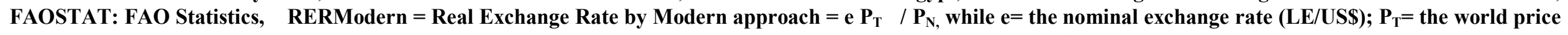
of tradable in terms of foreign currency, $P_{N}=$ the price of non-tradable goods. (Diakosavvas, D., and Kirkpatrik, $C$., 1990). 
التأثير المحتمل لسياسة تعويم سعر الصرف على الميزان التجاري المصري والتجارة الزر اعية وتجارة الأغذية الميز

د/ أحمد قردي مختار محمد بهلول

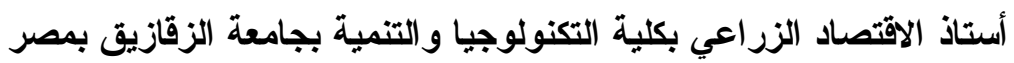

وأستاذ بجامعة أم القرى بمكة المكرمة بالسعودية.

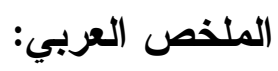

مرت مصر بتاريخ طويل من المشاكل المتعلقة بسعر صرف الجنيه المصري بالــدو لار الأمريكيـي

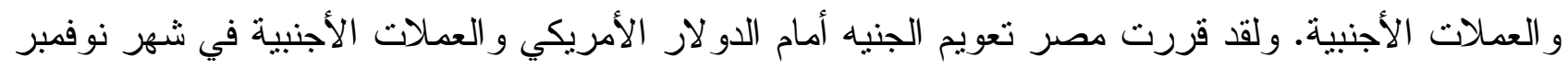

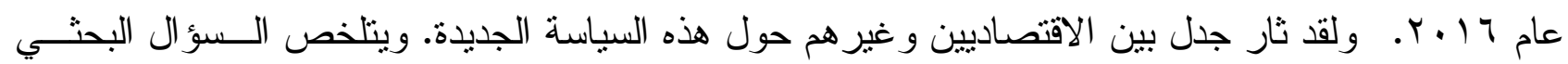

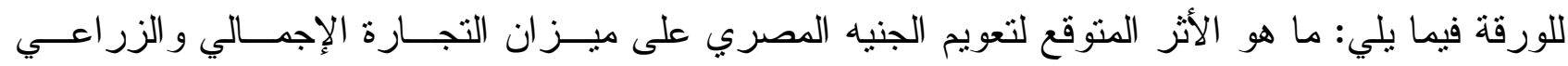



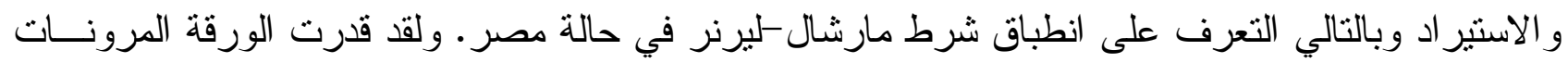



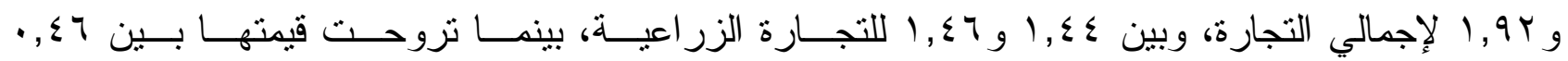

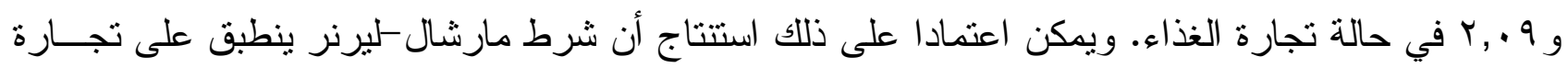

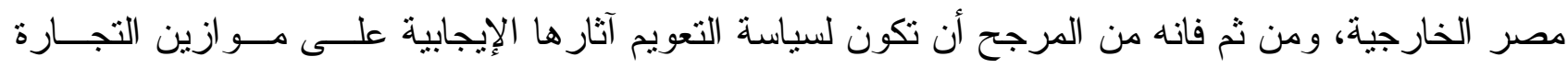

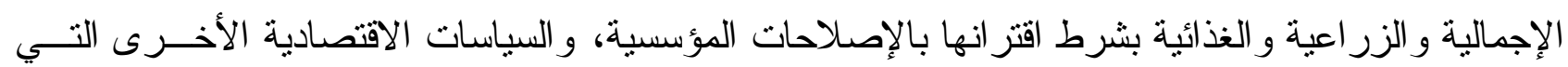
تعزز نتائجها الإيجابية وتخفف من آثار ها السلبية. 